\title{
Structure and ultrastructure of the labial salivary glands in patients with cystic fibrosis
}

\author{
R. G. DOGGETT, ${ }^{1}$ B. BENTINCK, ${ }^{2}$ AND G. M. HARRISON
}

From the Departments of Pediatrics and Rehabilitation, Baylor College of Medicine, and the Texas Institute for Rehabilitation and Research, Houston, Texas, USA

SYNOPSIS The morphology of the labial salivary glands in subjects with and without cystic fibrosis has been studied by light and electron microscopy. The terms 'light' cell, 'dark' cell, 'clear' cell, and 'myoepithelial' cell are used to describe the four cell types distinguished at the level of the electron microscope. The dark cells were found to stain specifically with alcian blue at and above $p \mathrm{H} 1 \cdot 0$, and the light cells to stain specifically using the periodic acid-Schiff (PAS) technique. This staining reaction suggests that an acidic mucosubstance is being produced by the dark cells and a neutral mucosubstance by the light cells. While no marked morphological differences were observed in the labial glands of patients with cystic fibrosis when contrasted with normal controls, it was observed that the cells from patients with cystic fibrosis contained quantitatively more mucus.

Despite intensive studies, the basic morphological or biochemical defect in cystic fibrosis remains unknown. The disease is considered to result from abnormal secretions of the mucous glands of the body. Approximately $98 \%$ of patients with cystic fibrosis have more than $60 \mathrm{~m}$-equiv/l of chloride in their sweat; the discovery of elevated sweat electrolytes (Darling, di Sant' Agnese, Perena, and Andersen, 1953) has proved to be the most consistent tool to confirm diagnosis. The sweat glands, however, show no morphological abnormalities by either light (Andersen, 1962) or electron microscopy (Munger, Brusilow, and Cooke, 1961).

Increased electrolytes and organic non-electrolytes have been reported in mucus-secreting glands other than the sweat glands. Chernick and his coworkers (Chernick, Barbero, and Parkins, 1961; Chernick, Eichel, and Barbero, 1964) reported that calcium, total protein, and amylase are raised in submaxillary saliva from subjects with cystic fibrosis. These findings have been supported and furthered by Mandel, Kutscher, Denning, Thompson, and Zegarelli (1967) who state that submaxillary saliva in cystic fibrosis is markedly altered in contrast to the overall com-

Received for publication 3 August 1970.

${ }^{1}$ Please send requests for reprints to R. G. Doggett, Texas Institute for Rehabilitation and Research, 1333 Moursund Avenue, Houston, Texas.

${ }^{2}$ Present address: Methodist Hospital, Texas Medical Center, Houston Texas 77025 . position noted in the parotid secretion. They observed that submaxillary secretions in cystic fibrosis exhibit increased concentrations of sodium, chloride, calcium, and phosphorus; urea and uric acid; and total protein, amylase, lysozome, and protein-bound hexose and fucose. However, Lev and Spicer (1965) found no qualitatively abnormal mucins in mucus-secreting tissue when they histochemically contrasted specimens from subjects with cystic fibrosis with specimens from those without who had mucous hypersecretion due to some other disease. The morphological normality, or abnormality, of the major salivary glands of individuals with cystic fibrosis remains unsubstantiated.

The rectal mucous glands of patients with cystic fibrosis have been reported to be abnormal (Rizk and Kissane, 1959; Marks and Anderson, 1960; Eidelman, Dobbins, Porus, Docter, Lobeck, and Rubin, 1964; Hunton, Long, and Tsumagari, 1966; Jabro and Gibbs, 1966). Jabro and Gibbs (1966) have suggested the use of rectal biopsies as a diagnostic aid. The primary criterion for an interpretation of 'positive for cystic fibrosis' is obvious crypt dilatation.

In 1963 Meskin, Warwick, and Bernard reported pathological changes in the minor salivary glands of patients with cystic fibrosis. They suggested that lip biopsies might be used for diagnostic purposes since the labial mucous salivary glands were found to be pathologically abnormal in about $80 \%$ of 
patients with cystic fibrosis (Meskin, Bernard, and Warwick, 1964; Warwick, Bernard, and Meskin, 1964). The diagnostic criteria were as follows: dilatation of ducts; increased numbers of ducts; accumulation of eosinophilic plaques within the ductal lumen; dilatation of the acini with accumulation of mucin within the acini; decrease in alcian blue staining of the acinar cells; metaplasia of the ductal epithelium; atrophy of the acinar cells; and cyst-like dilatation of the acini. In 1967, Sweney, Hedrick, Lawrence, Meskin, and Warwick studied the minor labial salivary glands, seeking to distinguish normal patients not only from patients with cystic fibrosis but also subjects heterozygous for the cystic fibrosis gene. Those authors concluded from this investigation that eosinophilic plugs occur frequently in the acini of the labial mucous salivary glands of children with cystic fibrosis while similar changes are rare in normal children. This criterion cannot be used to identify the heterozygote. In 1968, Sweney and Warwick reported on ultrastructural changes of the labial salivary glands in patients with cystic fibrosis. The only morphological change consistently seen was the presence of homogeneous eosinophilic plugs in the cystic fibrosis glands in light microscopic studies. In their electron microscopic studies the only consistent changes were the plugs and the cells which enclosed the plugs, suggesting that the plugs had formed in acinar tissue.

Recently, Tandler and his colleagues (Tandler and Denning, 1966; Tandler, Denning, Mandel, and Kutscher, 1969) presented the ultrastructure of normal human acinar secretory cells of the labial salivary glands. They concluded from their work that the acinar cells are pure mucus in nature with no serous elements present. This group described immature cells and stated that the acinar cells were found at all stages of maturation.

The purpose of this study was to compare by light and electron microscopy the morphology of labial salivary glands of normal subjects with those of patients with cystic fibrosis. Of particular interest were the possibilities of using these glands for histochemical studies if they were patently affected in cystic fibrosis patients and exploring their use in assessing the behaviour of intracellular mucins in the presence or absence of respiratory tract infection (Doggett, Harrison, Stillwell, and Wallis, 1966).

\section{Materials and Methods}

Specimens of minor salivary glands were obtained in the operating rooms of the Texas Institute for Rehabilitation and Research in Houston, Texas. Biopsies were taken from 20 patients with cystic fibrosis of both sexes ranging in age from 4 to 18 years, most of whom were undergoing bronchial lavage (Cezeaux, Telford, Harrison, and Keats, 1967). The majority of these patients were clinically classified as having advanced disease. Tissue was taken from 12 control patients of both sexes without cystic fibrosis ranging in age from 3 to 16 years while the subjects were under general anaesthesia for corrective orthopaedic surgery.

Before bronchial lavage sodium pentobarbital was given orally and scopolamine hydrobromide was administered intramuscularly to the patients with cystic fibrosis. Anaesthesia was induced with pentothal sodium and maintained with $0.25 \%$ to $0.5 \%$ halothane in oxygen. A muscle relaxant, succinylcholine chloride, was administered intravenously before tracheal intubation.

After lavage tissue was excised from the inner surface of the lower lip with a $3 \mathrm{~mm}$ biopsy punch. It was immediately dropped into a pool of fixative and cut into pieces of $1 \mathrm{~mm}$ or less in diameter. Some of the tissue was cut in strips $3 \mathrm{~mm} \times 1 \mathrm{~mm}$; also, individual whole glands were fixed. After cutting the tissue was transferred to a vial of fresh fixative for one hour. The fixatives employed were $1 \%$ or $2 \%$ osmium buffered with veronal (Palade, 1952 ), $2 \%$ osmium buffered with phosphate (Millonig, 1961), or $2.5 \%$ gluteraldehyde buffered with phosphate (Sabatini, Bensch, and Barrnett, 1963). Specimens were fixed for one hour at room temperature, and those fixed in gluteraldehyde were postfixed for one hour in veronal-buffered osmium. The tissue was dehydrated in a series of graded alcohols followed by propylene oxide. It was then embedded in Araldite 501 and serially polymerized in ovens at $35^{\circ}, 45^{\circ}$, and $60^{\circ} \mathrm{C}$. for eight to 12 hours in each. Sections were cut with a Sorval MT-2 or LKB ultratome. Thick sections for orientation were cut 1 to 2 microns and stained with toluidine blue or Paragon. Thin sections were cut in the gray-silver range. They were placed on uncoated grids, stained for five minutes with lead citrate (Reynolds, 1963) and examined and photographed in the Hitache HU-11B.

For light microscopy entire uncut biopsies and individual whole glands were fixed for one and a half hours in phosphate-buffered gluteraldehyde or in $10 \%$ buffered neutral formalin, dehydrated, and embedded in Paraplast. Sections were cut 4 to 7 microns. Alternatively, for better evaluation of cellular damage, 1 to 2 micron sections were cut of Araldite-embedded tissue. They were mounted on slides and treated for 30 seconds to one minute in sodium methoxide to remove the resin (Mayor, Hampton, and Rosario, 1961). Staining time was extended.

The alcian blue method for acid carbohydrates was used as described by Mowry (1956). It was found 
to apply equally to Paraplast or Araldite-embedded tissues regardless of fixative.

The periodic acid-Schiff (PAS) technique (McManus, 1948) was used to demonstrate neutral mucosubstances in gluteraldehyde or formalinfixed, paraffin-embedded tissues, but found to be inapplicable to osmium-fixed, Araldite-embedded tissue.

\section{Results}

\section{CELL TYPES}

Human minor salivary glands lie beneath the epithelial and connective tissue layers in the lower lip (Fig. 1). They are of the compound tubuloalveolar type. The acini consist of two secretory cell types which have been termed mucous and serous by histologists. The mucous cells produce secretion droplets which were found to be strongly alcian blue positive at $p \mathrm{H} 2.5$ (Fig. 2). They will be called dark cells in this paper in reference to this affinity. In addition, because of an inherent electron density and an affinity for lead, the secretion droplets of dark cells appear dark in electron micrographs (Fig. 3). The other type of acinar secretory cell will be termed light cell. Light cell secretion droplets did not stain with alcian blue, and they showed little affinity for lead, giving the cells the overall appearance of being light in comparison to the dark cells in both light and electron micrographs.
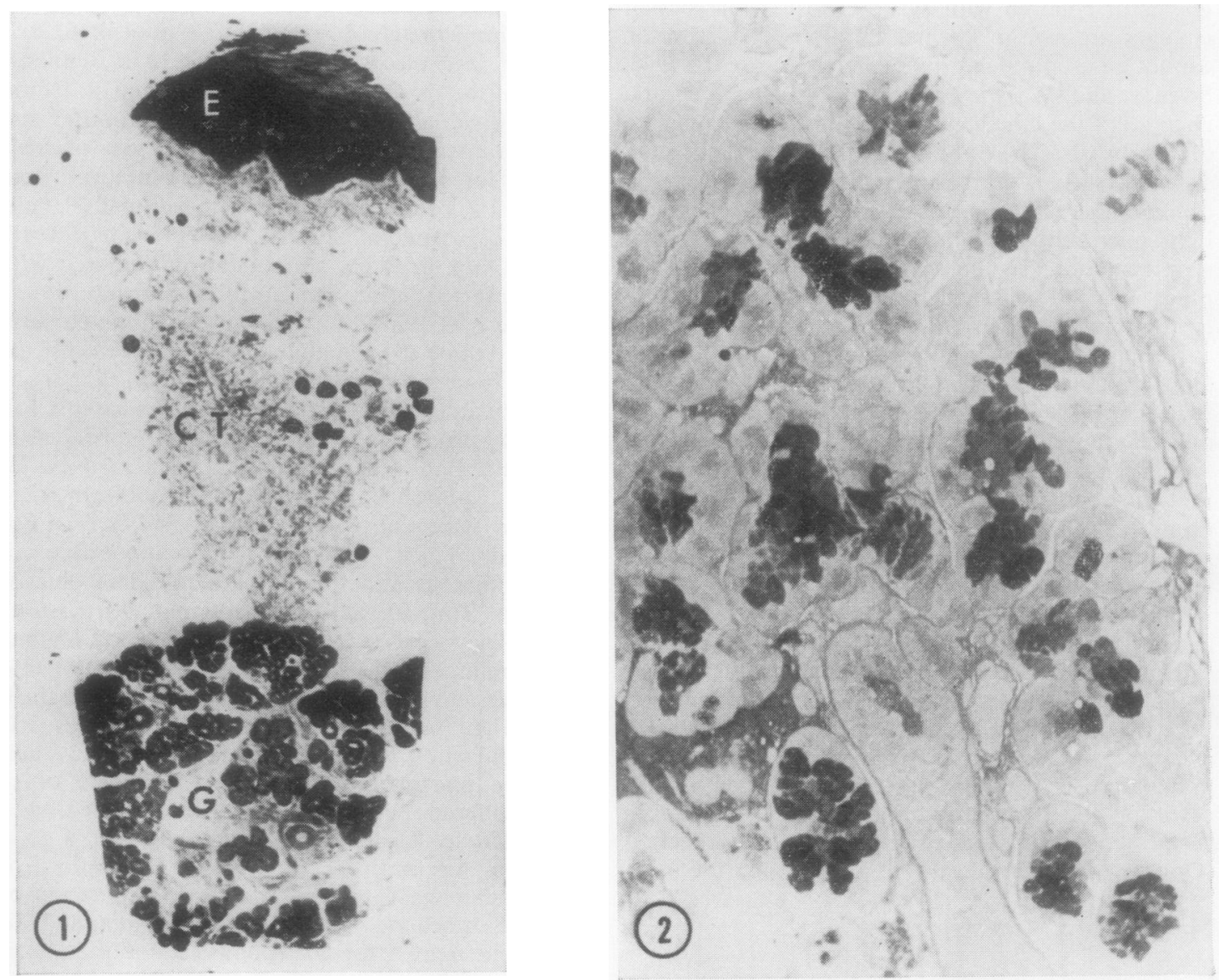

Fig. 1. A section through the lower lip of a patient with cystic fibrosis, illustrating the relationship of the glandular layer $(\mathrm{G})$, to the connective tissue layer $(\mathrm{CT})$, and epithelium $(\mathrm{E})$. The stain is toluidine blue $(\times 36)$.

Fig. 2. Labial mucous salivary gland from a patient with cystic fibrosis illustrating the reaction of the dark cells with alcian blue $(\times 213)$. 


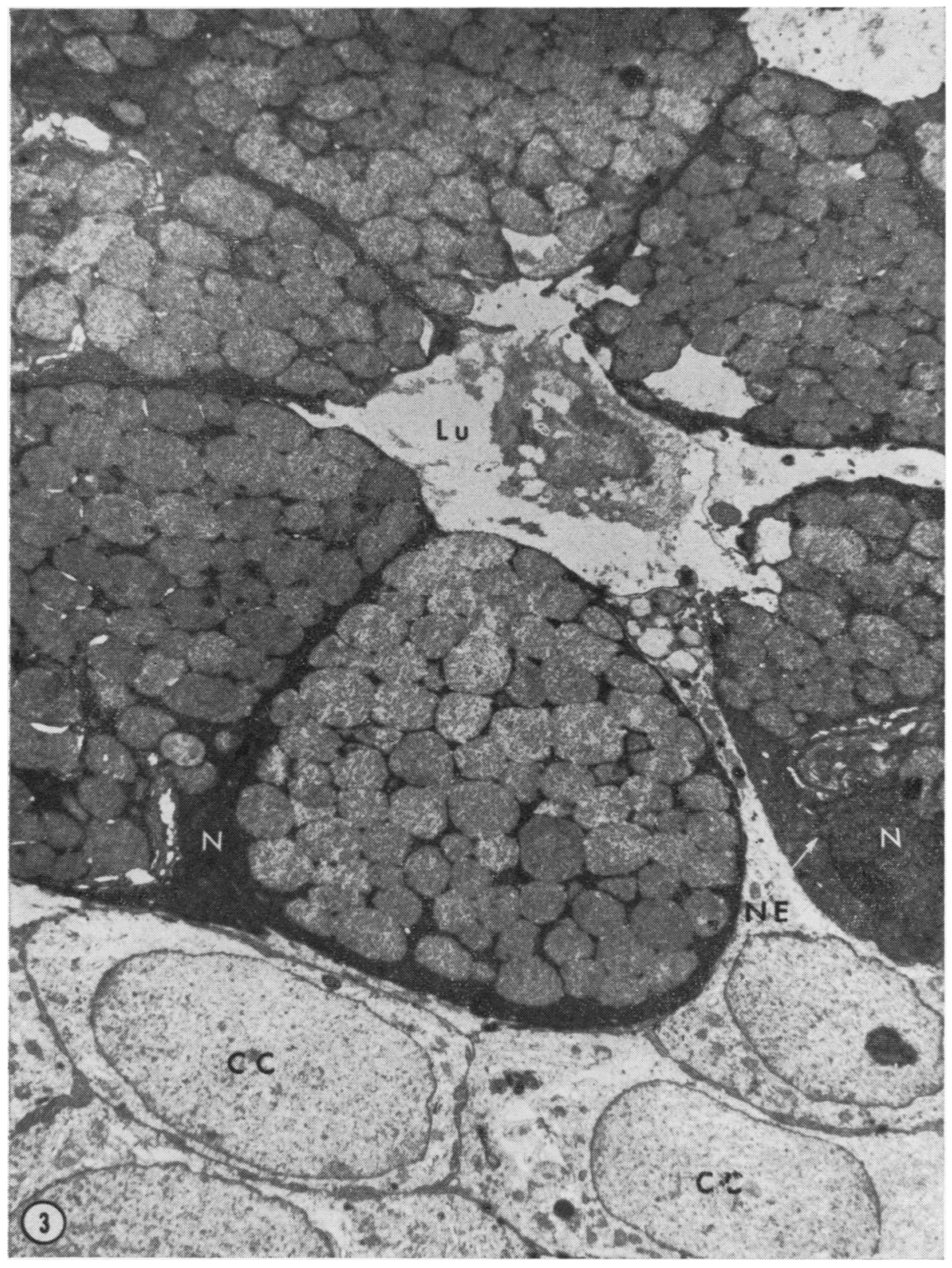

Fig. 3. Electron micrograph of a dark cell acinus. The lumen (lu), the nuclei of dark cells (N), nuclear envelope (NE), and clear cells (CC) are indicated $(\times 6,500)$. (This specimen was from a 15-year-old patient with cystic fibrosis in an advanced state of the disease. The patient died less than three months after biopsy.) 

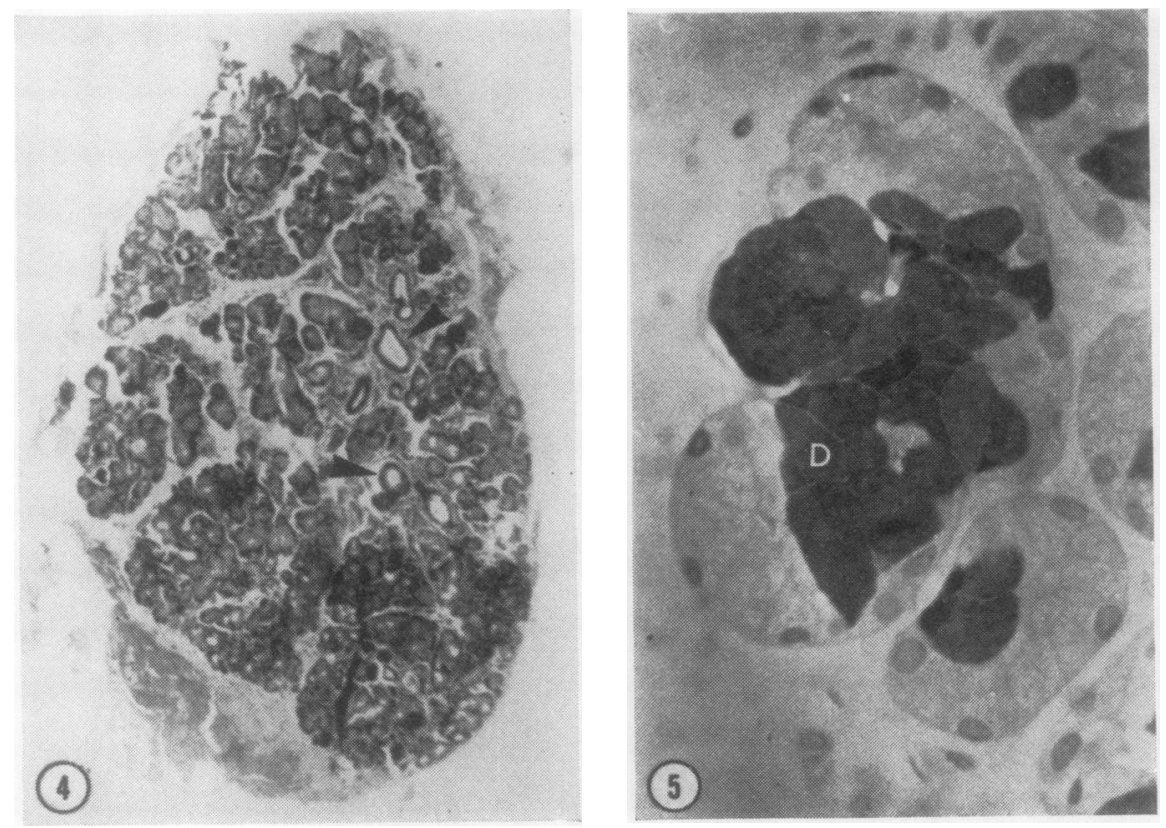

Fig. 4. Non-cystic fibrosis labial salivary gland. Arrows indicate ducts which appear dilated. The stain is $H \& E(\times 44)$.

Fig. 5. Labial salivary gland from a patient with cystic fibrosis illustrating the alcianophilia of dark cells $(D)(\cdots 634)$.

Acini were seen to consist of all dark cells, all light cells, or a combination of the two. The great majority of the acini were mixed, with the light cells appearing as demilunes around the dark cells.

\section{CYSTIC FIBROSIS LABIAL GLANDS}

In contrast to the work of Warwick and co-workers (Meskin et al, 1963 and 1964; Warwick et al, 1964; Sweney et el, 1968; Sweney and Warwick, 1968), no apparent pathological changes in the labial glands of children with cystic fibrosis were found and no significant differences between their labial glands and those of children without cystic fibrosis were noted. The severity of the disease in the cases of cystic fibrosis used in this study can be termed advanced since seven of the 20 subjects we biopsied have since died. Alcian blue staining was consistent. Eosinophilia of ductal contents occurred in formalinfixed tissue while no increase in eosinophilic plugs (Sweney and Warwick, 1968) was observed in patients with cystic fibrosis. Normal glandular structures were present in all cases. Apparent dilated acini and ducts were occasionally seen, but these were consistently present in the control tissue from children without cystic fibrosis (Fig. 4).
MUCIN CONTENT

Considerable difficulty in terminology arises in the classification of carbohydrate-protein complexes. Biochemical analysis of the carbohydrate moiety has been completed for only a handful of these substances, and histochemical methods provide limited information. Accordingly, we have used the term mucosubstance as suggested by Spicer, Leppi, and Stoward (1965). The more specific terms, mucopolysaccharide, glycoprotein, or mucoprotein, cannot presently be justified on a biochemical basis with reference to the mucins of the human minor salivary glands.

Mowry's alcian blue method (1956) for acid carbohydrates applied to sections of any of the tissues prepared, regardless of fixative or embedding medium, stained selectively the secretion droplets in the apex of the dark cells (Fig. 5). These cells, whose secretion droplets stained with alcian blue at $p \mathrm{H} 2.5$ and $p \mathrm{H} 1 \cdot 0$, corresponded in form and distribution to the dark cells. Alcian blue intensely stained the contents of acinar lumens and ducts. The staining reaction was unaffected by treatment with sialidase. The secretion droplets of the peripheral light cells were unstained. 


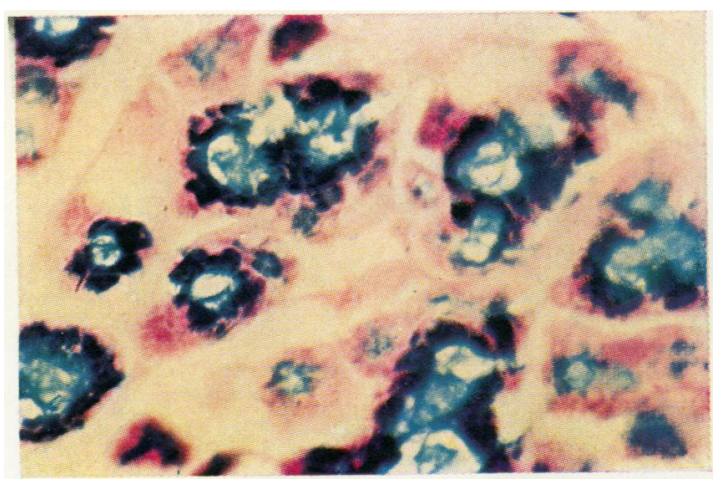

Fig. 6. Labial gland from a patient with cystic fibrosis indicating the PAS-positive reaction in the peripheral light cells and $A B$ reaction in the dark cells ( $>667)$.

McManus's PAS technique (1948) for neutral mucosubstances was found to be applicable only to gluteraldehyde or formalin-fixed, paraffin-embedded tissue. In these tissues, it gave a strong PASpositive reaction in the secretion droplets of the peripheral light cells. The dark cell secretion droplets stained faintly, if at all. Small amounts of PASpositive material were also present in the acinar lumens and ducts.

When the two stains, alcian blue and PAS, were overlaid, as suggested by Mowry (1960), it was apparent that they were staining selectively. There was little material present that stained the various shades of purple associated with colour action by both alcian blue and PAS. Droplets in dark cells and material in acinar lumens and ducts stained clear blue; light cell droplets and small amounts of material in lumens and ducts stained clear red (Fig. 6).

It appears that two different secretory cell types produce two different secretory products which leave the acini by common lumens and ducts. The dark cells apparently produce an acid mucosubstance; the light cells apparently produce a neutral mucosubstance. No attempt was made to quantitate the light and dark cells with reference to the two subject groups. Light microscopy using toluidine blue consistently demonstrated quantitative increases in the intercellular mucin in subjects with cystic fibrosis.

ULTRASTRUCTURE OF ACINI

At the level of the electron microscope, four cell types can be distinguished: dark cells, light cells myoepithelial cells, and clear cells. All four types are shown in a single 'mixed' acinus in Figure 7. Dark cells are roughly pyramidal in shape. They are very crowded with dense secretion droplets and the nuclei and cell organelles are displaced basically. The area around and including the nucleus is so electrondense that the nuclear envelope can barely be distinguished in low magnification micrographs (Fig. 3). The secretion droplets of the dark cells are membrane bound within the cells. Surface specializations include extensive lateral interdigitations which bind the dark cells to each other and to each of the other cell types. Desmosomes are scattered along opposing cell surfaces and a terminal bar appears near the apex of the cell where it borders on a lumen. The luminal surface is relatively smooth.

Light cells are also roughly pyramidal in shape. Within the cell the basal nucleus is surrounded by an extensive endoplasmic reticulum (Fig. 8). Large Golgi networks are conspicuous in the perinuclear region. The apical portion of the cell is crowded with pale membrane-bound droplets which contain varying amounts of fibrillar and granular material. Occasionally, droplets within a light cell may be seen to contain a small dense zone which may represent an artifact in fixation (Fig. 9). Similar variations in secretion droplets have been reported by Kurtz (1964), Parks (1962), and Scott and Pease (1959) in work with minor salivary glands from rats and mice. Lateral interdigitations and junctional complexes are present as noted for dark cells. Intercellular canaliculi are common between light cells (Fig. 9). Occasionally a dark cell may be seen to border on an intercellular canaliculus together with several light cells (Fig. 10). Light and dark cells also frequently border on the same lumen (Fig. 7). Microvilli extend into the intercellular canaliculi. By contrast, the luminal cell surface is relatively smooth.

Myoepithelial cells lie between the basal plasmalemma of the acinar cells and the basement layer. They are stellate in form with long, slender processes extending over the acinus and giving rise to the term 'basket cell'. Three myoepithelial cells are seen in Figure 9. The section passed through the nucleus of one and through the processes of two other myoepithelial cells. The cytoplasm of myoepithelial cells contains bundles of filaments which resemble those of muscle. Apparently the function of this cell type is to act as a smooth muscle cell. The myoepithelial cell contracts, causing secretion by syueezing of the acini. This process has been observed directly by Hurley and Shelly (1954) in sweat glands. With the exception of the muscle filaments, organelles are not prominent in myoepithelial cells. A small Golgi network occurs near the nucleus. Mitochondria are sparse and the endoplasmic reticulum is limited to a few cisternae. Scattered lipid droplets are present.

The term clear cell has been restricted to those 


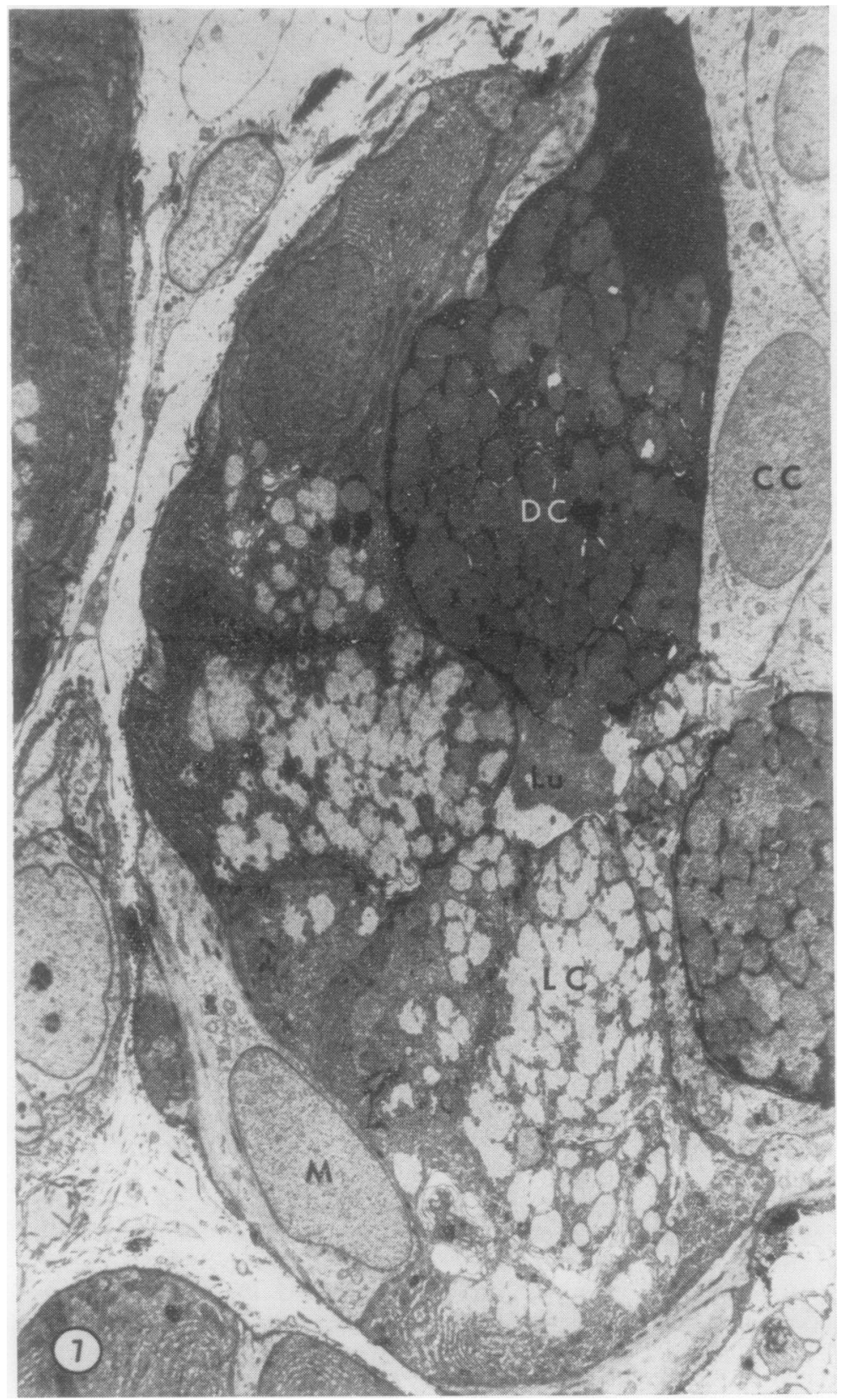

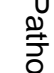




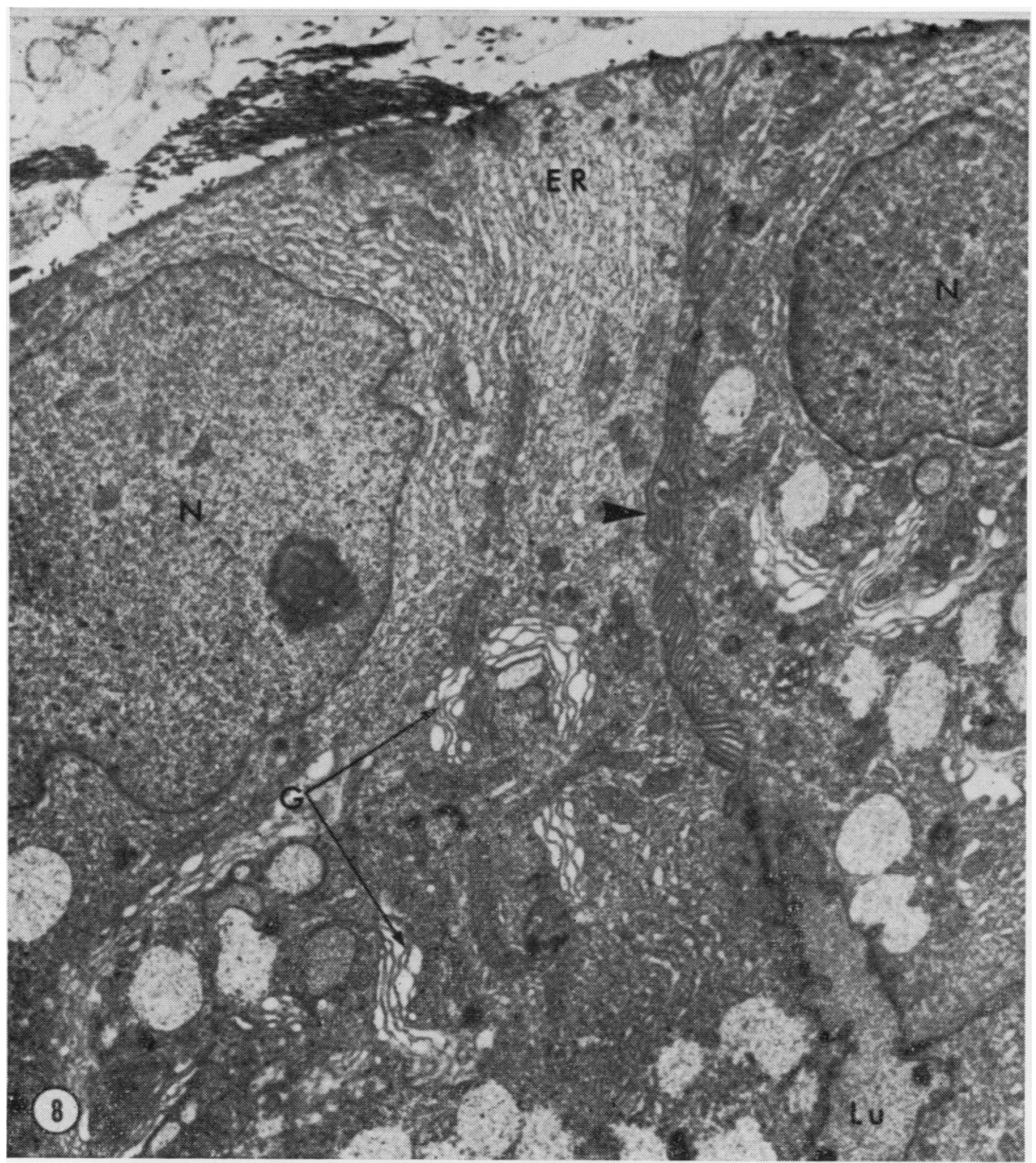

Fig. 8. Micrograph of light cells from a patient with cystic fibrosis. Extensive lateral interdigitations are seen at the arrow and the nuclei $(\mathrm{N})$, endoplasmic reticulum (ER), Golgi (G) and lumen $(\mathrm{L})$ are labelled $(\times 8,500)$.

cells with an extremely lucent cytoplasm and almost no organelles or inclusions as described by Tandler (1965) (Figs. 3, 7, 11). Clear cells are similar to myoepithelial cells, and intermediate forms appear to exist. Tandler (1965) has described cells with the myofilaments and lipid droplets of the myoepithelial cell and the electron-lucent cytoplasm of the clear cell. It seems likely, therefore, that the clear cell is an immature myoepithelial cell. Two of the three clear cells in Fig. 11 are seen to border on a lumen. Myofilaments are not yet present within these cells.

\section{Discussion}

Comparison of the labial salivary glands from patients with cystic fibrosis and from control children without cystic fibrosis by means of light and electron microscopy has been undertaken to determine whether structural abnormality is present in these particular glands. On the basis of comparative morphology and ultrastructure, minor salivary glands from children with cystic fibrosis were indistinguishable from those of children without the disease 


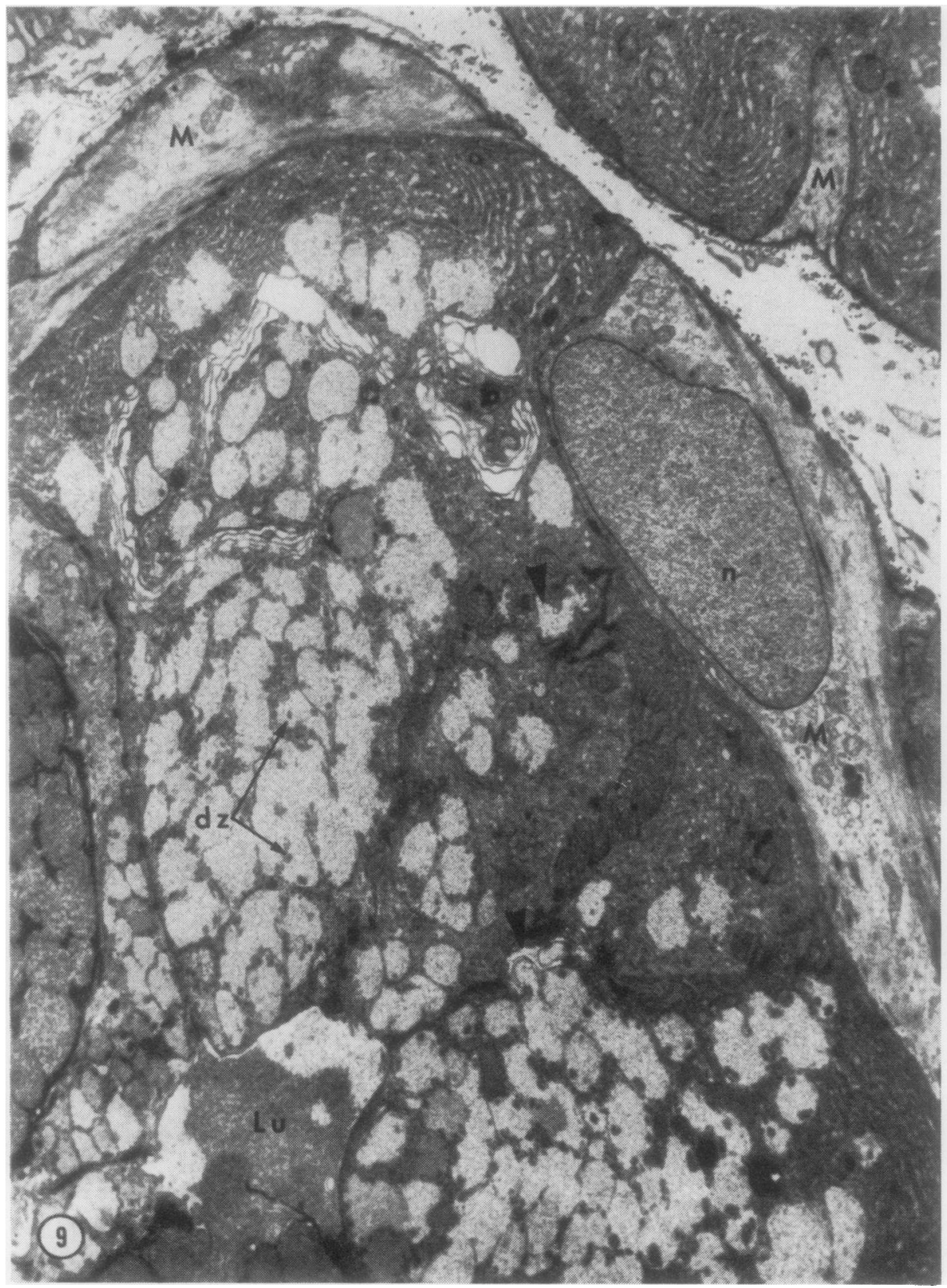




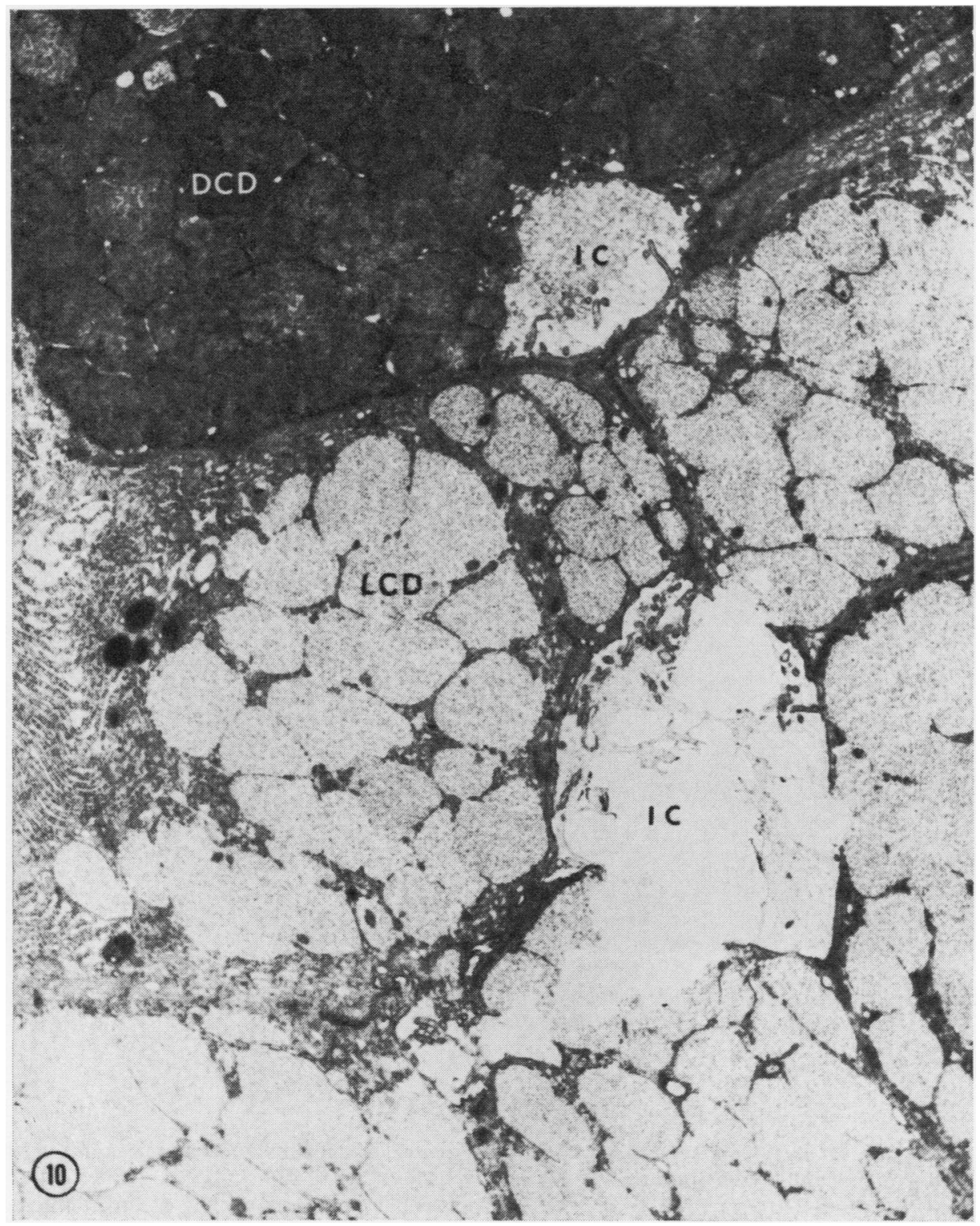

Fig. 10. Micrograph showing two intercellular canaliculi (IC). Dark cells and light cells appear to border on the same canaliculus in the upper portion of the micrograph. Light cell droplets (LCD) are observed to have lysed and emptied into the lower intercellular canaliculus $(\times 12,000)$. The labial glands are from a patient without cystic fibrosis. 


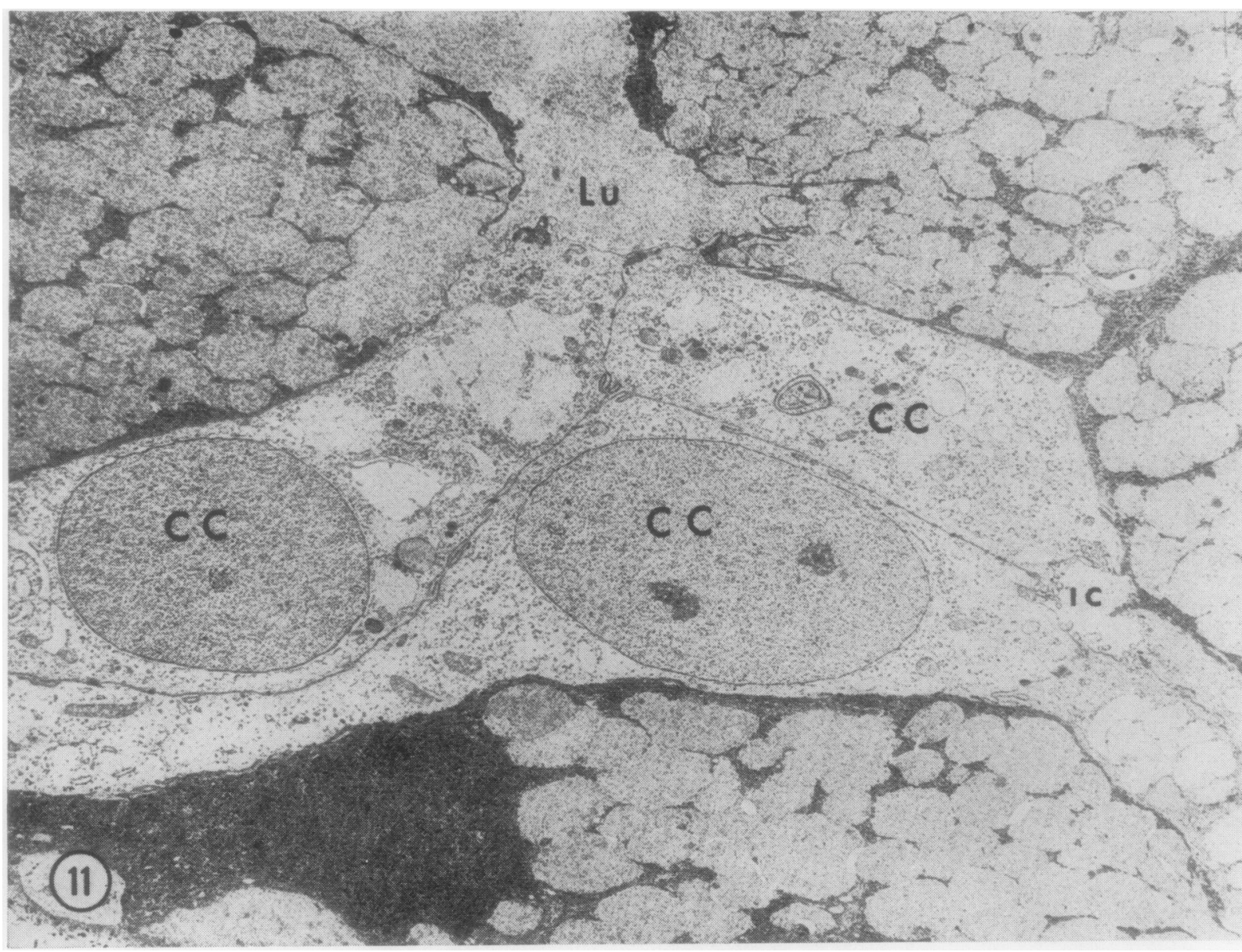

Fig. 11. In this micrograph two clear cells (CC) are seen bordering the lumen (Lu). An intercellular canaliculus (IC) is also present $(\times 6,200)$. This specimen is from a patient with cystic fibrosis.

It appears that there are at least two secretory cell types in the acini, and that these cell types produce different secretory products. It has been suggested that light cells are merely immature dark cells. However, specific reactions with PAS and alcian blue resolved the presence of different materials within the same lumen and duct, revealing that light cells produce a distinct secretion and are not immature dark cells. Electron micrographs show light cell droplets being emptied into lumens and intercellular canaliculi (Fig. 10), further suggesting that their secretion products and the cells themselves are mature. Alcian blue staining at $p \mathrm{H} 1.0$ confirms that the dark cell is producing a highly acidic substance, while light cells appear to be pro- ducing a neutral mucosubstance which stains with PAS.

The four cell types apparent by electron microscopy have been termed dark cells, light cells, clear cells, and myoepithelial cells. The terms dark cell and clear cell have been previously used by Montagna, Chase, and Lobitz (1953), Munger et al (1961), and Ellis (1964) in reference to sweat gland acini. Clear cell has been used by these authors to denote the peripheral cells of the acini. Intercellular canaliculi exist between these cells, and a secretory function is postulated for them although no secretory vacuoles are seen (Munger et al, 1961). We have used the term clear cell, instead, as suggested by Tandler, to describe a non-mucoid, non-nervous, 
non-secretory cell with an extremely electron-lucent cytoplasm. Such cells have been reported previously by Parks (1961) and Tandler (1965). The term light cell has been applied to the peripheral cells of minor salivary gland acini. They are clearly secretory in nature with membrane-bound secretion droplets.

Staining with toluidine blue demonstrated that the cells from patients with cystic fibrosis contain more mucin than the cells from the control group. The marked quantitative increase in mucins of other mucus-secreting cells in many organs of the body in patients with cystic fibrosis has previously been described (Lev and Spicer, 1965).

One interesting observation was the difference in the integrity of the connective tissue of the two groups of subjects. The epithelial layer would consistently pull apart from the glandular layer in the cases of cystic fibrosis when the whole biopsy specimens were cut into strips for fixation. The connective tissue layer remained intact while slicing the control subject's biopsies. The significance of this remains to be elucidated.

Salivary gland abnormalities in cystic fibrosis may be dependent on the type of secretion they produce. The parotid glands produce a secretion that is mainly serous, and usually do not exhibit any demonstrable morphological changes. However, pathological changes are noted in the submaxillary gland which secretes large amounts of glycoprotein. The failure to find significant morphological changes in the labial glands in this study may be a reflection of the mucins they produce. The finding that different cell types synthesize different mucosubstances may be nature's way of offsetting tissue damage. Those glands with cells which can only synthesize similar mucosubstances but which exhibit properties of polydispersity with respect to certain features of their carbohydrate content may become altered in the course of events leading to hypersecretion.

This investigation was supported by the Research and Training Center project RT-4 from the Social and Rehabilitation Service, the Brown Foundation of Houston, and the National Cystic Fibrosis Research Foundation.

\section{References}

Andersen, D. H. (1962). Pathology of cystic fibrosis. Ann. N.Y. Acad. Sci., 93, 500-517.

Cezeaux, G., Jr., Telford, J., Harrison, G., and Keats, A. S. (1967). Bronchial lavage in cystic fibrosis. J. Amer. med. Ass., 199, 15-18.

Chernick, W. S., Barbero, G. J., and Parkins, F. M. (1961). Studies on submaxillary saliva in cystic fibrosis. J. Pediat., 59, 890-898.

Chernick, W. S., Eichel, H. J., and Barbero, G. J. (1964). Submaxillary salivary enzymes as a measure of glandular activity in cystic fibrosis. J. Pediat., 65, 694-700.
Darling, R. C., di Sant' Agnese, P. A., Perera, G. A., and AndersenD. H. (1953). Electrolyte abnormalities of the sweat in fibro, cystic disease of the pancreas. Amer. J. med. Sci., 225, 67-70.

Doggett, R. G., Harrison, G. M., Stillwell, R. N., and Wallis, E. S. (1966). An atypical Pseudomonas aeurginosa associated with cystic fibrosis of the pancreas. J. Pediat., 68, 215-221.

Eidelman, S., Dobbins, W. O., Porus, R. L., III, Docter, J. M., Lobeck C. C., and Rubin, C. E. (1964). Rectal mucosal changes in cystic fibrosis: frequency and specificity in a large series of proven cases. Cystic Fibrosis Club Abstracts, Fifth Annual Meeting, Seattle.

Ellis, R. A. (1964). The fine structure of some salt-secreting epithelia. In Research on Pathogenesis of Cystic Fibrosis, pp. 1-16. Proc. IIIrd Internat. Conf. N.I.H., Bethesda.

Hunton, D. B., Long, W. K., and Tsumagari, H. Y. (1966). Meconium ileus equivalent: An adult complication of fibrocystic disease. Gastroenterology, 50, 99-106.

Hurley, H. J., and Shelley, W. B. (1954). The role of the myoepithelium of the human apocrine sweat gland. J. invest. Derm., 22, 143156.

Jabro, I. H., and Gibbs, G. E. (1966). Rectal mucosal biopsies as a diagnostic aid in cystic fibrosis. J.-Lancet, 86, 385-388.

Kurtz, S. M. (1964). Electron Microscopic Anatomy. Academic Press, New York.

Lev, R., and Spicer, S. S. (1965). A histochemical comparison of human epithelial mucins in normal and in hypersecretory states including pancreatic cystic fibrosis. Amer. J. Path., 46, 23-47.

McManus, J. F. A. (1948). Histological and histochemical uses of periodic acid. Stain Technol., 23, 99-108.

Mandel, I. D., Kutscher, A., Denning, C. R., Thompson, R. H., Jr., and Zegarelli, E. (1967). Salivary studies in cystic fibrosis. Amer. J. Dis. Child., 113, 431-438.

Marks, B. L., and Anderson, C. M. (1960). Fibrocystic disease of the pancreas in a man aged 46. Lancet, 1, 365-367.

Mayor, H. D., Hampton, J. C., and Rosario, B. (1961). A simple method for removing the resin from epoxy-embedded tissue. J. Biophys. biochem. Cytol., 9, 909-910.

Meskin, L. H., Bernard, B., and Warwick, W. J. (1964). Biopsy of the labial mucous salivary glands in cystic fibrosis. J. Amer. med. Ass., 188, 82-83.

Meskin, L. H., Warwick, W. J., and Bernard, B. (1963). Pathological changes in the minor salivary glands in cystic fibrosis. (Abstr.) Fed. Proc., 22, 276.

Millonig, G. (1961). Advantages of a phosphate buffer for Os O, solutions in fixation. (Abstr.) J. appl. Phys., 32, 1637.

Montagna, W., Chase, H. B., and Lobitz, W. C. (1953). Histology and cytochemistry of human skin. IV. The eccrine sweat glands. J. invest. Derm., 20, 415-423.

Mowry, R. W. (1956). Alcian blue technics for the histochemical study of acidic carbohydrates. J. Histochem. Cytochem., 4, 407.

Mowry, R. W. (1960). Manual of Histologic Staining Methods of the Armed Forces Institute of Pathology, 2nd ed., pp. 142-144. Armed Forces Institute of Pathology, Washington.

Munger, B. L., Brusilow, S. W., and Cooke, R. E. (1961). An electron microscopic study of eccrine sweat glands in patients with cystic fibrosis of the pancreas. J. Pediat., 59, 497-511.

Palade, G. E. (1952). A study of fixation for electron microscopy. J. exp. Med., 95, 285-297.

Parks, H. F. (1961). On the fine structure of the parotid gland of mouse and rat. Amer. J. Anat., 108, 303-329.

Parks, H. F. (1962). Morphological study of the extrusion of secretory materials by the parotid glands of mouse and rat. J. Ultrastruct. Res., 6, 449-465.

Reynolds, E.S. (1963). The use of lead citrate at high $\mathrm{pH}$ as an electronopaque stain in electron microscopy. J. Cell Biol., 17, 208-212.

Rizk, V. E., and Kissane, J. M. (1959). Adult mucoviscidosis. Amer. J. Med., 27, 483-493.

Sabatini, D. D., Bensch, K., and Barrnett, R. J. (1963). Cytochemistry and electron microscopy. The preservation of cellular ultrastructure and enzymatic activity by aldehyde fixation. $J$. Cell Biol., 17, 19-58.

Scott, B. L., and Pease, D. C. (1959). Electron microscopy of the salivary and lacrimal glands of the rat. Amer. J. Anat., 104, 115-161.

Spicer, S. S., Leppi, T. J., and Stoward, P. J. (1965). Suggestions for a histochemical terminology of carbohydrate-rich tissue components. J. Histochem. Cytochem., 13, 599-603. 
Sweney, L., Hedrick, M. C., Lawrence, C. M., Meskin, H., and Warwick, W. J. (1967). The involvement of the labial mucous salivary gland in patients with cystic fibrosis. II. The heterozygote state. Pediatrics, 40, 421-424.

Sweeney, L., and Warwick, W. J. (1968). Involvement of the labial salivary gland in patients with cystic fibrosis. III. Ultrastructure changes. Arch. Path., 86, 413-418.

Tandler, B. (1965). Ultrastructure of the human submaxillary gland. III. Myoepithelium. Z. Zellforsc $h ., 68,852-853$.
Tandler, B., and Denning, C. R. (1966). Ultrastructure of human labial salivary gland acini, with special reference to intranuclear inclusions. (Abstr.). J. Cell Biol, 31, 116A-117A.

Tandler, B., Denning, C. R., Mandel, I. D., and Kutscher, A. H. (1969). Ultrastructure of human labial salivary glands. I. Acinar secretory cells. J. Morph., 127, 383-389.

Warwick, W. J., Bernard, B., and Meskin, L. H. (1964). The involvement of the labial mucous salivary gland in patients with cystic fibrosis. Pediatrics, 34, 621-628.

\section{The March 1971 Issue}

\section{THE MARCH 1971 ISSUE CONTAINS THE FOLLOWING PAPERS}

Cytodiagnosis of rheumatoid pleural effusions $\mathrm{M}$. M. BODDINGTON, A. I. SPRIGGS, J. A. MORTON, AND A. G. MOWAT

The development of a urological cytodiagnosis service and an evaluation of its success P. N. COWEN

Effect of carbenicillin, gentamicin, and their combination on experimental Pseudomonas aeruginosa urinary tract infection L. KONÍČKOVÁ AND V. PRÁT

Isolation of Bacteroids corrodens from infections in children H. B. MARSDEN AND W. A. HYDE

False positive Wassermann reaction associated with evidence of enterovirus infection R. A. QUAIFE AND J. V. T. GOSTLING

The preservation of gonococci in liquid nitrogen M. E. WARD AND P. J. WATT

Proteins and fibrinolysis in recipients of renal allografts E. N. WARDLE, I. S. MENON, P. R. ULDALL, AND J. SWINNEY

Hepatic and serum folates in patients fasting and after oral folic acid D. W. DAWSON AND C. GEARY

Partial villous atrophy in nutritional megaloblastic anaemia corrected by folic acid therapy D. W. DAWSON
Plasminogen assay by a haemagglutination inhibition technique c. A. LUDLAM AND P. C. DAS

The British system for anticoagulant control and Thrombotest L POLLER, JEAN M. THOMPSON, AND M. R. ALDERSON

A combined qualitative and quantitative procedure for the chemical analysis of urinary calculi A. HODGKINSON

A clinical and electron microscopic study of a calcifying epithelial odontogenic tumour A. R. MAINWARING, ALI AHMED, J. M. HOPKINSON, AND P. ANDERSON

Reprint No. 2

The perinatal postmortem examination

F. A. LANGLEY

Equipment for linking the AutoAnalyzer on-line to a computer D. SIMPSON, G. E. SIMS, M. I. HARRISON, AND L. G. WHITBY

\section{Technical methods}

Simple inexpensive micro method for the estimation of $T_{3}$ uptake $\mathrm{W}$. W. WALTHER

Demonstration of sensitized lymphocytes in blood E. J. FIELD AND E. A. CASPARY

Letters to the Editor

Book reviews

Copies are still available and may be obtained from the PUBLISHING MANAGER, BRITISH MEDICAL ASSOCIATION, TAVISTOCK SQUARE, WC1H 9JR price $£ 1.05$ 